\title{
A falconid from the Late Miocene of northwestern China yields further evidence of transition in Late Neogene steppe communities
}

\author{
Zhiheng Li, ${ }^{1 *}{\text { Zhonghe } \mathrm{Zhou}^{2}{ }^{2} \mathrm{Tao} \text { Deng, }}^{2}$ Qiang $\mathrm{Li}^{2}{ }^{2}$ and Julia A. Clarke ${ }^{1}$ \\ 1 Department of Geological Sciences, Jackson School of Geosciences, University of Texas at Austin, Austin, Texas, USA \\ ${ }^{2}$ Key Laboratory of Vertebrate Evolution and Human Origins, Institute of Vertebrate Paleontology and Paleoanthropology, Chinese \\ Academy of Sciences, Beijing, China \\ * Corresponding author: zhiheng_li@utexas.edu
}

Received March 25, 2014; Accepted March 28, 2014; Published June 4, 2014

\begin{abstract}
Although the family Falconidae, which includes extant falcons and caracaras, has a long evolutionary history, most previously reported fossils referred to this family are isolated single elements. We report a new species, Falco hezhengensis sp. nov., represented by a nearly complete and articulated skeleton from the Late Miocene deposits of Linxia Basin in northwestern China. The new fossil shares an array of derived morphologies with the genus Falco, and analysis of the largest morphological dataset for Falconidae, sampling most genera, identifies the specimen as a new stem kestrel. The phylogeny shows a high degree of congruence with published molecular phylogenies and time trees supporting a Miocene radiation of Falconidae. The species provides a new calibration for the divergence of extant kestrels from other Falco. Remains of a small mammal, a jerboa (Dipodidae), are preserved in the abdominal region of the specimen. Integrated with data from other avian remains from the Linxia Basin, the new fossil provides further support for changes in the open steppe environment of Central Asia since the Late Miocene. Changes in falconid ecology and diet, shifts in small-mammal abundances, as well as the extinction of the Central Asian ostrich may be involved in community turnover in the Late Neogene.
\end{abstract}

Keywords: Aves, Falco, fossil, jerboa, Late Miocene, Linxia Basin

\section{Un Falcónido del Mioceno tardío del noroeste de China brinda evidencia adicional de la transición en las comunidades de estepa del Neógeno tardío}

\section{RESUMEN}

Aunque los Falconidae, que incluye halcones y caracaras vivientes, tienen una larga historia evolutiva, la mayoría de los fósiles previamente reportados para esta familia son elementos únicos aislados. Aquí reportamos una nueva especie, Falco hezhengensis sp. nov., representada por un esqueleto casi completo y articulado de los depósitos del Mioceno tardío de la Cuenca de Linxia en el noroeste de China. El nuevo fósil comparte un conjunto de morfologías derivadas con el género Falco, y el análisis de la mayor base de datos morfológicos para Falconidae, con muestras de la mayoría de los géneros, identifica el espécimen como un nuevo cernícalo basal. La filogenia muestra un alto grado de congruencia con las filogenias moleculares y los árboles de tiempo publicados que apoyan una radiación de Falconidae en el Mioceno. La especie brinda una nueva calibración para la divergencia entre los cernícalos vivientes y el resto de los Falco. Los restos de un pequeño mamífero, un gerbo (Dipodidae), están preservados en la región abdominal del espécimen. En conjunto con datos de otros restos de aves de la Cuenca de Linxia, el nuevo fósil brinda sustento adicional para los cambios en el ambiente de estepa abierta de Asia Central desde el Mioceno tardío. Los cambios en la ecología y la dieta de los falcónidos, las fluctuaciones en la abundancia de los pequeños mamíferos, así como la extinción del avestruz de Asia Central pueden estar involucrados en el recambio comunitario del Neógeno tardío.

Palabras clave: Aves, Cuenca de Linxia, Falco, fósil, Gerbo, Mioceno Tardío

\section{INTRODUCTION}

The Falconidae are a monophyletic group of diurnal birds of prey that occupy a wide variety of ecological niches and have a global extant distribution (White et al. 1994). This clade has 3 recognized subclades-Herpetotherinae (laughing falcon and forest falcon), Falconinae (typical falcons, kestrels, and falconets), and Polyborinae (caracaras)-that have been supported by analyses of both molecular and morphological datasets (Griffiths 1999, Griffiths et al. 2004, Fuchs et al. 2012). Most Falconidae are small to medium aerial predators that feed on insects, amphibians, lizards, turtles, snakes, birds, and small mammals, whereas the caracaras are specialized scaven- 

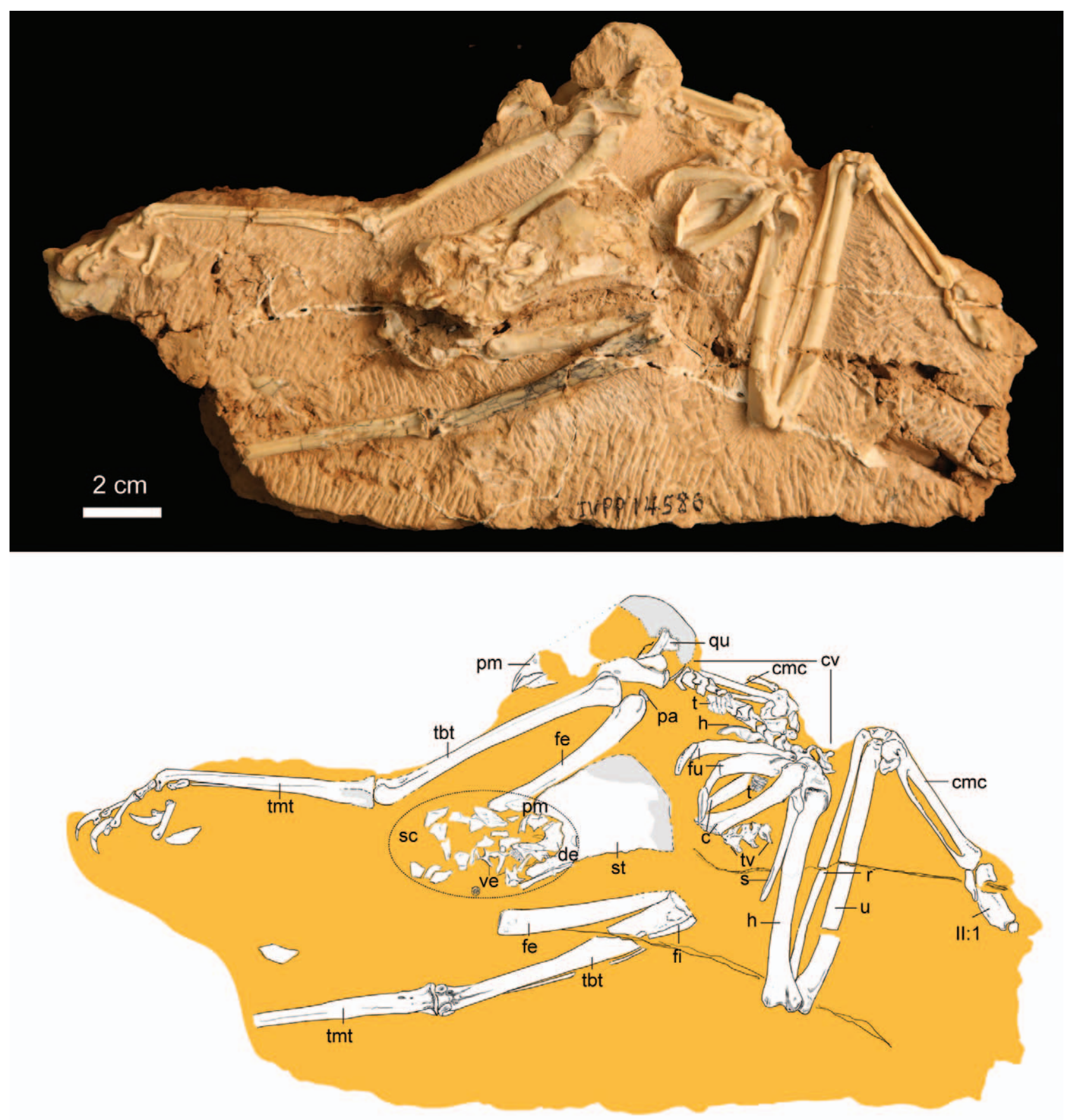

FIGURE 1. Photograph and line drawing of the holotype specimen of Falco hezhengensis (IVPP V14586). Anatomical abbreviations: $\mathrm{c}$ $=$ coracoid, $\mathrm{cmc}=$ carpometacarpus, $\mathrm{cv}=$ cervical vertebrae, de $=$ dentary, fe $=$ femur, $\mathrm{fi}=$ fibula, fu $=\mathrm{furcula}, \mathrm{h}=\mathrm{humerus}, \mathrm{pa}=$ patella, $\mathrm{pm}=$ premaxilla, $\mathrm{qu}=$ quadrate, $\mathrm{r}=$ radius, $\mathrm{s}=\mathrm{scapula}, \mathrm{sc}=$ stomach contents, $\mathrm{st}=\mathrm{sternum}, \mathrm{r}=\mathrm{radius}, \mathrm{t}=\mathrm{tracheal}$ rings, tbt $=$ tibiotarsus, $\mathrm{tv}=$ thoracic vertebrae, $\mathrm{tmt}=$ tarsometatarsus, ve $=$ vertebrae, $\mathrm{u}=\mathrm{ulna}$, and $\|-1=$ phalanx $\|-1$.

gers that occasionally consume plant material (Fuchs et al. 2012).

The specimen reported here, from the Miocene of northwestern China, consists of a nearly complete, articulated skeleton with the remains of a small rodent in the abdominal region (Figure 1). One of the best- preserved specimens of a fossil falconid yet recovered, it is arguably rivaled only by a partial skeleton from the Miocene of South America (Thegornis; Noriega et al. 2011). The new specimen exhibits better preservation of the forelimb and the pectoral girdle elements but is less complete in the pelvic girdle than the Thegornis specimen 
(Noriega et al. 2011). Although an array of falconid species have been described, primarily from the Neogene of Eurasia and America, most are based on isolated and incomplete limb bones, and careful taxonomic reevaluation is required (Boev 2011a, 2011b).

Paleogene Falconidae are known only from fragmentary remains (e.g., distal tarsometatarsi and a pedal phalanx) and are considered problematic (Feduccia 1999, Mayr 2009b). More complete material, including multiple skeletons, is known for the Eocene taxon Masillaraptor, but its affinities have been considered uncertain because of homoplasy observed among traditional parts of "Falconiformes" (Mayr 2006, 2009a, 2009b). For instance, Masillaraptor shares a more abbreviated first phalanx of the second digit with Accipitridae, but a well-developed zygomatic process with Falconidae (Mayr 2006, 2009a). Accipitridae has not been supported as closely related to Falconidae in recent analyses of molecular data; the latter is recovered in a clade including parrots, songbirds, and seriemas (Hackett et al. 2008, McCormack et al. 2013, Yuri et al. 2013). PrePleistocene remains referred to Polyborinae include 2 incomplete tarsometatarsi known from the Late Eocene of Antarctica (Tambussi and Acosta Hospitaleche 2007) and the Pliocene of Chile (Emslie and Correa 2003). The referral of the former to even the more inclusive clade Falconidae has been questioned (Mayr 2009b). A pedal phalanx, also from the Eocene of Antarctica, was quite recently referred to Falconidae but also has yet to be assessed in a broader phylogenetic context (Tambussi and Degrange 2013). The late Early Miocene Thegornis musculosus and T. debilis from Patagonia were originally described as falconids from fragments of distal tarsometatarsi (Ameghino 1895). Analysis of recently referred specimens of Thegornis, including a partial skeleton, confirms a close relationship to the clade Herpetotherinae (Noriega et al. 2011).

Pre-Pleistocene specimens from Europe are primarily referred to Falconinae (Boev 2011ab). A number of species have been named (e.g., Falco bulgaricus), but most are based on isolated bones (limb elements, coracoids, furculae, phalanges, etc.) from Late Miocene to Pliocene (Boev 2011a, 2011b). The record of Falconidae in Eurasia has been similarly scarce: Only 1 species (F. medius) is considered valid (Boev 2011a), represented by a left carpometacarpus from the Late Miocene of Ukraine (Umanskaja 1981). Pediohierax ramenta, from the midMiocene of Nebraska, has been considered the earliest reliable record of Falconinae (Wetmore 1936, Becker 1987). It is known from multiple, isolated postcranial bones (e.g., tarsometatarsus, humerus, and coracoid), but so far it is not known from associated material.

More than 100 mammalian fossil localities have been identified in Oligocene-Pleistocene deposits of the Linxia
Basin of Gansu Province (Figure 2). However, the new specimen, from the Late Miocene Liushu Formation, represents only the third avian record from this basin. Miocene sites have been the most fossiliferous basin-wide, and all known avian specimens are from these sites (Deng et al. 2013). The pelvis of a stem-lineage ostrich (Struthionidae) and the skeleton of an Old World vulture, Gansugyps linxiaensis (Aves: Accipitridae), were previously reported from localities in Guanghe, Gansu Province (Hou et al. 2005, Zhang et al. 2010; Figure 2). The Late Miocene Linxia fauna is dominated by a diverse assemblage of mammals, including Hipparion, Chilotherium, Cervavitus, and Gazella (Deng 2005). The paleoenvironment represented by the Late Miocene Liushu Formation deposits has been interpreted as a subarid open steppe, dominated by xerophilous and subxerophilous grasses (Deng 2006).

\section{METHODS}

Osteological terminology follows Baumel and Witmer (1993), and English equivalents of the Latin osteological nomenclature are used when available. Institutional abbreviations: IVPP $=$ Institute of Vertebrate Paleontology and Paleoanthropology; TMM = Texas Memorial Museum; and USNM = National Museum of Natural History, Smithsonian Institution.

Osteological and morphometric comparisons were made with skeletal materials of a broad array of extant species of Falconidae as well as outgroup taxa (USNM and TMM collections). Primary reference species for the morphological characters evaluated are as follows: Caracara plancus, Phalcoboenus carunculatus, Daptrius americanus, Milvago chimachima, Spiziapteryx circumcincta, Microhierax erythrogenys, Polihierax insignis, F. rupicoloides, F. tinnunculus, F. peregrinus, Herpetotheres cachinnans, Micrastur ruficollis, Circus buffoni, Buteo lagopus, and Cariama cristata. Only the relatively completely known extinct falconid taxa Thegornis musculosus and Pediohierax ramenta were assessed from the literature (Becker 1987, Noriega et al. 2011) for inclusion in the phylogenetic analyses. Measurements and limb ratios for the new Falco, 18 extant and 1 extinct, Falco species are provided in Tables 1 and 2 and are shown in Figure 3.

\section{RESULTS}

\section{Systematic Paleontology}

Aves Linnaeus, 1758

Falconidae Leach, 1820

Falco hezhengensis sp. nov.

Holotype. IVPP V14586, comprising a nearly complete articulated skeleton, lacking only part of the orbital region of the skull, thoracic and caudal vertebrae, most of 


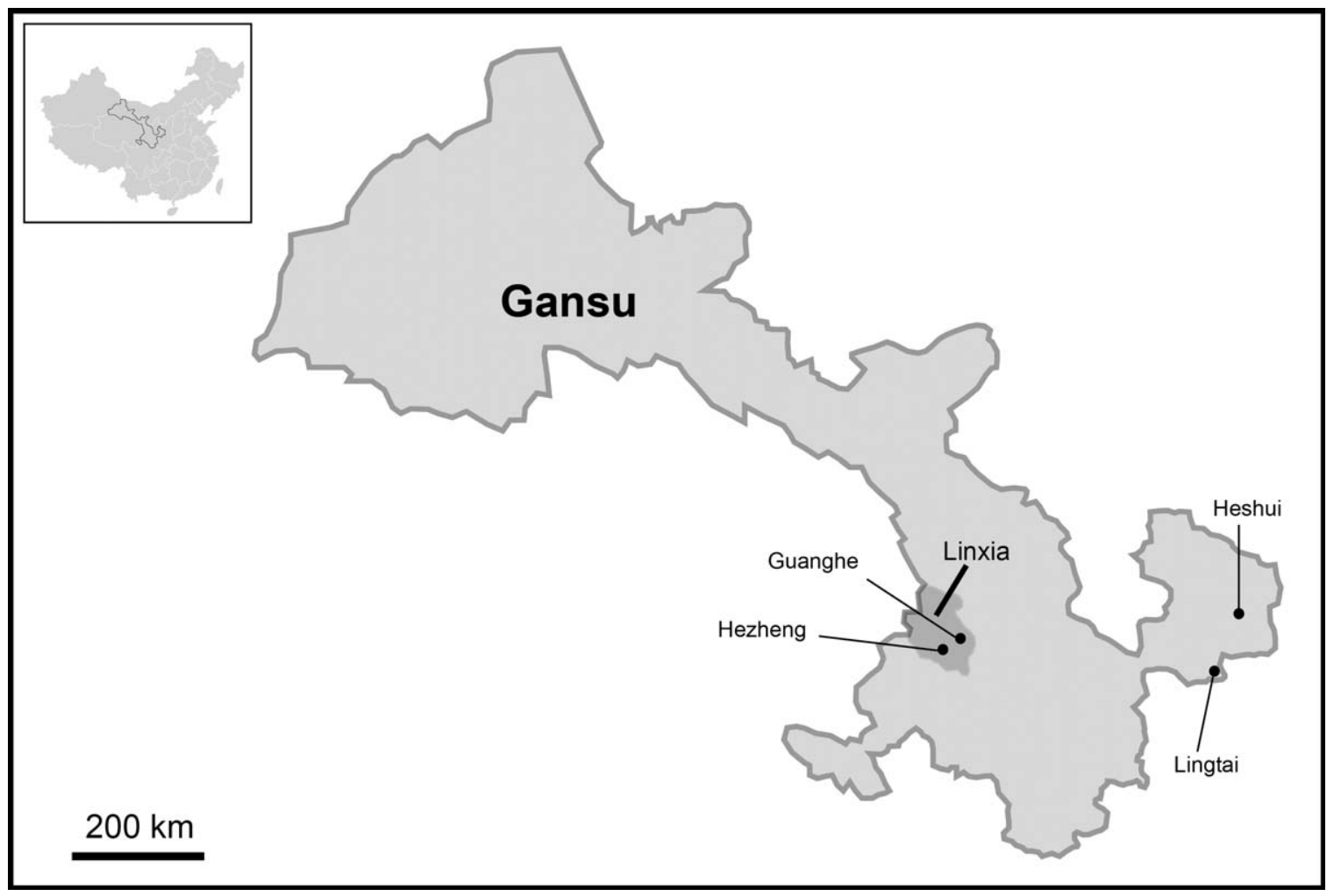

FIGURE 2. Miocene vertebrate fossil localities of Gansu Province, northwestern China, that are referenced in the text. The holotype specimen is from the Linxia region; previously reported bird fossils are from Guanghe; and jerboa fossils are known from Heshui and Lingtai.

the pelvic girdle, and the left pes (Figures 1, 4, 5, 6, and 7).

Diagnosis. Identification of the new species as part of Falconidae is supported by 2 unambiguously optimized synapomorphies that are not present in other "Falconiformes": On the cranial surface of the distal tibia, medial to the supratendinal bridge, a conspicuous deep depression or perforated opening into the extensor groove is present (character 47:1-3), and the medial hypotarsal crest of the tarsometatarsus is distally extensive (character 52:1-2). Both features have been previously proposed to be diagnostic of Falconidae (e.g., Jollie 1976, 1977a, 1977b, 1977c, Suárez and Olson 2001, Noriega et al. 2011). In the new species, the region next to the supratendinal bridge is specifically conformed as a perforated opening, a feature shared with Falconinae and Polyborinae but not Herpetotherinae within Falconidae. Character numbers reference Supplemental Material Appendix S1.

Synapomorphies shared with parts of extant Falconinae and not present in other Falconidae include a prominent tomial notch on the premaxilla (character 1:1), the length of the orbital process of the quadrate shorter than that of the otic process (character 14:1), and the flexor process of the humerus surpassing the ventral condyle in distal extent. These morphologies were previously recognized as diagnostic characters of Falconinae (Jollie 1976, 1977a, 1977b, 1977c, Solti 1996, Noriega et al. 2011). Within Falconinae, the new specimen differs from the falconets but is similar to other Falco in possessing a relatively more elongate rostrum (character 2:1). The humerus of the new species also shares features of the bicipital crest and the transverse groove with Falco that are not present in falconets (characters 33 and 35). For example, the bicipital crest of the humerus in the new species has a greater distal extent and meets the humeral shaft obliquely. It is relatively shorter and meets the shaft at closer to a right angle in falconets. Finally, the transverse groove shallows toward the humeral midline in falconets, whereas it is deeper in the new species and other Falco.

The new species is differentiated from all other Falco by the presence of an ovoid depression below the coronoid process on the external surface of the mandible and a more pronounced ridge on the ventral midline of the rostral premaxillae (septal bar). Pneumatic openings on the dorsolateral surfaces of the neural arch in the 9th and 10th vertebrae are also notably smaller than those of extant Falco (character 20:2). Although the development of these openings varies among Falco species, they are unique to Falco within Falconidae and further support the affinities of the new species with that clade. Finally, the olecranon 
TABLE 1. Length measurements $(\mathrm{mm})$ and ratios of hindlimb elements of Falco hezhengensis sp. nov. in comparison with extant falcons (materials from USNM). Anatomical abbreviations: $\mathrm{Cmc}=$ carpometacarpus, $\mathrm{Fe}=$ femur, $\mathrm{Hu}=$ humerus, Tib $=$ tibiotarsus, Tmt $=$ tarsometatarsus, and $\mathrm{UI}=$ ulna. Even though not all Falco species have been incorporated here, representatives of all size ranges are included. The measurements of extinct Cuban Falco (F. kurochkini) are from Suárez and Olson (2001); the average length of the elements is provided.

\begin{tabular}{|c|c|c|c|c|c|c|c|c|c|}
\hline Species & Sex & $\mathrm{Hu}$ & UI & $\mathrm{Cmc}$ & $\mathrm{Fe}$ & Tib & Tmt & $\mathrm{Ti} / \mathrm{Tmt}$ & $\mathrm{Tmt} / \mathrm{Fe}$ \\
\hline Falco hezhengensis sp. nov. & $?$ & 62.0 & 69.4 & 39.8 & 47.3 & 67.0 & 55.3 & 1.2 & 1.2 \\
\hline F. kurochkini ${ }^{\dagger}$ & $?$ & 47.7 & & & 46.9 & 64.4 & 49.6 & 1.3 & 1.1 \\
\hline \multirow[t]{2}{*}{ F. rufigularis } & q & 50.8 & 57.2 & 33.6 & 44.5 & 58.7 & 37.2 & 1.6 & 0.8 \\
\hline & $\sigma$ & 48.0 & 53.5 & 31.6 & 41.6 & 54.7 & 33.7 & 1.6 & 0.8 \\
\hline F. rupicoloides & $\hat{\sigma}$ & 62.4 & 70.8 & 41.2 & 48.4 & 65.4 & 47.9 & 1.4 & 1.0 \\
\hline \multirow[t]{2}{*}{ F. subbuteo } & o & 57.4 & 65.0 & 38.7 & 44.8 & 57.2 & 34.9 & 1.6 & 0.8 \\
\hline & $\hat{0}$ & 51.6 & 59.2 & 35.5 & 41.5 & 52.5 & 33.7 & 1.6 & 0.8 \\
\hline F. cenchroides & 우 & 51.8 & 60.2 & 35.1 & 41.7 & 57.1 & 38.4 & 1.5 & 0.9 \\
\hline \multirow[t]{2}{*}{ F. columbarius } & o & 46.9 & 52.6 & 31.5 & 43.1 & 54.6 & 36.8 & 1.5 & 0.9 \\
\hline & q & 50.5 & 56.8 & 33.9 & 46.8 & 60.8 & 39.7 & 1.5 & 0.9 \\
\hline \multirow[t]{2}{*}{ F. tinnunculus } & ô & 56.5 & 64.0 & 37.2 & 45.6 & 61.3 & 41.3 & 1.5 & 0.9 \\
\hline & q & 54.3 & 61.7 & 33.7 & 44.0 & 58.1 & 38.3 & 1.5 & 0.9 \\
\hline F. vespertinus & o & 50.5 & 56.1 & 31.1 & 35.9 & 49.6 & 29.1 & 1.7 & 0.8 \\
\hline \multirow[t]{2}{*}{ F. moluccensis } & 우 & 53.2 & 60.7 & 41.7 & 45.3 & 61.4 & 41.7 & 1.5 & 0.9 \\
\hline & o & 52.1 & 59.6 & 34.8 & 44.4 & 59.7 & 41.3 & 1.4 & 0.9 \\
\hline \multirow[t]{2}{*}{ F. naumanni } & q & 49.3 & 56.8 & 33.1 & 33.7 & 47.2 & 29.6 & 1.6 & 0.9 \\
\hline & o & 53.2 & 56.5 & 31.9 & 37.0 & 48.5 & 31.5 & 1.5 & 0.9 \\
\hline F. cuvieri & $?$ & 52.9 & 60.4 & 37.3 & 42.7 & 57.1 & 34.2 & 1.7 & 0.8 \\
\hline \multirow[t]{2}{*}{ F. sparverius } & $\dot{0}$ & 40.9 & 46.9 & 27.0 & 35.3 & 48.3 & 34.7 & 1.4 & 1.0 \\
\hline & o & 39.1 & 43.0 & 22.9 & 36.5 & 49.9 & 36.7 & 1.4 & 1.0 \\
\hline F. femoralis & $\sigma^{\pi}$ & 57.7 & 66.6 & 38.8 & 51.3 & 66.2 & 45.0 & 1.5 & 0.9 \\
\hline \multirow[t]{2}{*}{ F. eleonorae } & $\hat{0}$ & 66.6 & 77.1 & 44.6 & 47.4 & 62.1 & 34.5 & 1.8 & 0.7 \\
\hline & q & 69.3 & 79.3 & 45.4 & 48.5 & 62.8 & 33.9 & 1.9 & 0.7 \\
\hline \multirow[t]{2}{*}{ F. mexicanus } & o & 68.9 & 81.9 & 49.8 & 61.8 & 78.6 & 51.0 & 1.5 & 0.8 \\
\hline & 우 & 84.5 & 99.1 & 58.8 & 71.6 & 91.4 & 57.45 & 1.6 & 0.8 \\
\hline F. biarmicus & 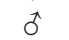 & 70.9 & 85.8 & 48.9 & 59.1 & 77.0 & 50.3 & 1.5 & 0.9 \\
\hline \multirow[t]{2}{*}{ F. peregrinus } & $\widehat{0}$ & 76.4 & 88.0 & 52.9 & 62.2 & 78.0 & 48.0 & 1.6 & 0.8 \\
\hline & q & 90.5 & 105.2 & 62.3 & 71.9 & 90.8 & 54.4 & 1.7 & 0.8 \\
\hline \multirow[t]{2}{*}{ F. cherrug } & 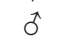 & 84.8 & 97.5 & 58.8 & 70.2 & 86.8 & 53.4 & 1.6 & 0.8 \\
\hline & q & 92.1 & 110.2 & 63.1 & 86.7 & 93.5 & 56.2 & 1.7 & 0.7 \\
\hline F. rusticolus & o & 100.8 & 113.3 & 66.9 & 85.4 & 101.4 & 59.1 & 1.7 & 0.7 \\
\hline
\end{tabular}

Note: Specimen numbers of extant falcons referred to are USNM 612263, USNM 344063, USNM 430626, USNM 621279, USNM 603410, USNM 620194, USNM 560083, USNM 610756, USNM 610371, USNM 610374, USNM 488841, USNM 560787, USNM 560786, USNM 603407, USNM 552902, USNM 18964, USNM 502729, USNM 558047, USNM 614586, USNM 488787, USNM 487652, USNM 614365, USNM 291404, USNM 322046, USNM 636772, USNM 622483, USNM 500263, USNM 500262, USNM 567722.

fossa of the distal humerus appears to be slightly deeper than that observed in other Falco.

The new species is also diagnosed by its hindlimb proportions. While $F$. hezhengensis is most similar in size to F. rupicoloides and F. subbuteo among extant falcons (Tables 1 and 2), it possesses a more elongate and slender tarsometatarsus (character 50:0). For example, the average tarsometatarsus length of $F$. rupicoloides is $\sim 48 \mathrm{~mm}$ (Table 1; also see Village 1990), $7 \mathrm{~mm}$ shorter than that of $F$. hezhengensis. This difference exceeds the known variance in tarsometatarsus length in falcon species (Table 2). The ratio of tibiotarsus to tarsometatarsus length is slightly less than that seen in other falcons (1.2 vs. $1.3 \sim 1.7)$, and the ratio of tarsometatarsus to femur length is greater than in all the other falcons (1.2 vs. 0.7 1.1; Table 1 and Figure 3).
The length of the third pedal digit is also more abbreviate in relation to tarsometatarsus length (42\%). It is significantly shorter than in all extant kestrels $(60-70 \%)$ and differs more markedly from other Falco (80-100\%; Village 1990). Measurements and limb ratios for 19 Falco species are provided in Tables 1 and 2 .

Locality and horizon. The fossil block containing the holotype specimen was collected from the Upper Miocene Liushu Formation (Deng 2005, Fang et al. 2003) of the Linxia Basin in Gansu Province, northwestern China (Figure 2). The Liushu Formation is composed of blocky and muddy siltstones, overlying the sandstones and conglomerates of Hujialiang Formation (Middle Miocene) and overlain by the conglomerates of Hewangjia Formation (latest Late Miocene-Early Pliocene; Deng et al. 
TABLE 2. Mean ( \pm SD) values of the limb-bone measurements adopted from Solti $(1981,1996)$. Anatomical abbreviations are the same as in Table 1.

\begin{tabular}{|c|c|c|c|c|}
\hline Bone & q & $n$ & $\hat{0}$ & $n$ \\
\hline \multicolumn{5}{|c|}{ Falco subbuteo } \\
\hline $\mathrm{Hu}$ & $57.53 \pm 2.12$ & 6 & $54.4 \pm 1.25$ & 11 \\
\hline UI & $65.89 \pm 1.33$ & 7 & $60.85 \pm 1.71$ & 11 \\
\hline $\mathrm{Cmc}$ & $39.87 \pm 0.41$ & 7 & $37.14 \pm 1.06$ & 11 \\
\hline $\mathrm{Fe}$ & $45.14 \pm 1.02$ & 11 & $43.13 \pm 1.96$ & 13 \\
\hline Tib & $55.91 \pm 1.15$ & 6 & $59.33 \pm 1.18$ & 10 \\
\hline Tmt & $34.41 \pm 0.79$ & 7 & $35.64 \pm 0.3$ & 11 \\
\hline \multicolumn{5}{|c|}{ F. columbarius } \\
\hline $\mathrm{Hu}$ & $50.51 \pm 1.26$ & 21 & $45.69 \pm 0.76$ & 15 \\
\hline UI & $56.77 \pm 1.2$ & 21 & $51.74 \pm 1.05$ & 15 \\
\hline $\mathrm{Cmc}$ & $34.34 \pm 0.79$ & 20 & $31.31 \pm 0.87$ & 16 \\
\hline $\mathrm{Fe}$ & $46.71 \pm 0.97$ & 21 & $43.63 \pm 0.86$ & 16 \\
\hline Tib & $58.43 \pm 1.16$ & 20 & $54.27 \pm 0.94$ & 15 \\
\hline Tmt & $38.02 \pm 0.9$ & 20 & $36.34 \pm 0.83$ & 17 \\
\hline \multicolumn{5}{|c|}{ F. tinnunculus } \\
\hline $\mathrm{Hu}$ & $54.44 \pm 2.07$ & 25 & $52.86 \pm 1.58$ & 16 \\
\hline UI & $62.43 \pm 2.16$ & 25 & $60.12 \pm 2.1$ & 17 \\
\hline $\mathrm{Cmc}$ & $36.24 \pm 1.46$ & 25 & $35.06 \pm 1.37$ & 14 \\
\hline $\mathrm{Fe}$ & $44.67 \pm 1.46$ & 26 & $44.4 \pm 1.02$ & 21 \\
\hline Tib & $59.8 \pm 1.92$ & 25 & $58.68 \pm 1.54$ & 13 \\
\hline Tmt & $40.53 \pm 1.25$ & 23 & $40.16 \pm 1.58$ & 13 \\
\hline \multicolumn{5}{|c|}{ F. vespertinus } \\
\hline $\mathrm{Hu}$ & $51.26 \pm 1.36$ & 14 & $50.3 \pm 1.37$ & 10 \\
\hline UI & $57.88 \pm 1.68$ & 14 & $57.0 \pm 1.82$ & 10 \\
\hline $\mathrm{Cmc}$ & $33.12 \pm 0.84$ & 14 & $36.62 \pm 0.88$ & 10 \\
\hline $\mathrm{Fe}$ & $36.8 \pm 1.02$ & 14 & $36.6 \pm 1.01$ & 11 \\
\hline Tib & $48.74 \pm 1.63$ & 14 & $48.04 \pm 1.24$ & 9 \\
\hline Tmt & $29.3 \pm 1.05$ & 13 & $29.1 \pm 0.87$ & 10 \\
\hline \multicolumn{3}{|c|}{ F. peregrinus (unknown sex) } & \multicolumn{2}{|c|}{ F. cherrug (unknown sex) } \\
\hline $\mathrm{Hu}$ & $86.7 \pm 4.4$ & 6 & $94.3 \pm 5.079$ & 6 \\
\hline UI & $97.1 \pm 7.9$ & 6 & $110.4 \pm 7.14$ & 5 \\
\hline $\mathrm{Cmc}$ & $60.6 \pm 4.3$ & 7 & $65.6 \pm 4.1$ & 6 \\
\hline $\mathrm{Fe}$ & $69.1 \pm 3.1$ & 4 & $74.6 \pm 2.3$ & 4 \\
\hline Tib & $91 \pm 4.9$ & 6 & $93.8 \pm 3.6$ & 5 \\
\hline Tmt & $54 \pm 2.8$ & 6 & $56.5 \pm 2.3$ & 6 \\
\hline
\end{tabular}

2013). The exact locality within the Linxia Basin is unknown, but the matrix of the fossil block consists of a light yellowish-brown carbonate-cemented siltstone (Figure 1), which is the dominant lithology of the "Hipparion fauna" beds within Liushu Formation (Deng 2006). These fossiliferous units are the most common in the basin and occur in siltstone units with interbedded layers of thick red clay (Deng 2005).

Etymology. The species name references the Hezheng, the county in Gansu Province where the largest collection of Cenozoic vertebrate fauna from the Linxia Basin are housed (Figure 2).

Description and comparisons. IVPP V14586 is a threedimensionally preserved, articulated skeleton exposed on the surfaces of a siltstone block (Figure 1). Parts of the rostrum, basicranium, mandible, and quadrate are pre- served, while much of the orbital area is missing (Figures 1 and 4). Falling within the size range of extant Falco, the new specimen is significantly larger in size than other small Falconinae (e.g., Spiziapteryx, Polihierax, and Microhierax).

The premaxilla is slightly hooked and surpasses the cranial tip of the mandible. Numerous neurovascular foramina are developed, and the specimen bears a notched tomial margin (Figure 4B: ntm). Such a "tooth-like" notch (Jollie 1976, 1977a, 1977b, 1977c) in the lateral edge of the tomial margin has been proposed to be used in killing and dismembering prey (White et al. 1994, Csermely et al. 1998). This feature is present in Falconinae (Falco, Microhierax, and Polihierax; Figure 4A, C, D) but absent in the rest of Falconidae. On the ventral midline of the fused premaxillae, a prominent ridge is developed. The projection of this ridge, or septal bar (Jollie 1976, 1977a, $1977 b, 1977 \mathrm{c}$ ), is more pronounced than in other Falco and other Falconidae more generally (e.g., Polihierax and Microhierax; Figure 4).

The rostrum of $F$. hezhengensis is comparatively short. The external nares are small and round, similar to the condition in other Falconinae (e.g., Falco, Microhierax, Polihierax, and Spiziapteryx). In other Falconidae (e.g., Micrastur and Caracara), the external nares may be ovoid. Posteriorly, the frontals are domed. The left quadrate is preserved in articulation with the mandible. The cranialmost tip of the orbital process of the quadrate is covered by matrix. However, compared with the length of otic process in the quadrate, its total length must have been discernibly shorter. The caudal margin of the otic process is bowed cranially, and the otic capitulum of the quadrate is well separated from the squamosal capitulum (Figure $4 \mathrm{~B})$. The coronoid process and lateral mandibular process are incompletely preserved. The area of the rostral mandibular foramen, ventral to the coronoid process, is occupied by a distinct shallow ovoid depression (Figure 4B: dep).

Ten cervical vertebrae are preserved in articulation, including the atlas and the axis (Figure 1). The ventral process of the atlas is exposed in lateral view. The 3rd to 10th cervicals are short. There are small foramina in the neural arch just cranial to the postzygapophyses of both the 9th and 10th cervicals. Larger foramina are observed in the same position in the 9th and 10th cervicals of some, but not all, extant Falco species (e.g., F. tinnunculus, F. rufigularis, and F. sparverius). Rounded depressions without perforation are present in this location in other Falco (e.g., F. rupicoloides and F. peregrinus) and falconid taxa (e.g., Microhierax).

With the exception of 3 poorly preserved thoracic or transitional cervicothoracic vertebrae exposed near the right coracoid (Figures 1 and 5A), none of the thoracic, sacral, or caudal vertebrae are visible. The 3 thoracic 

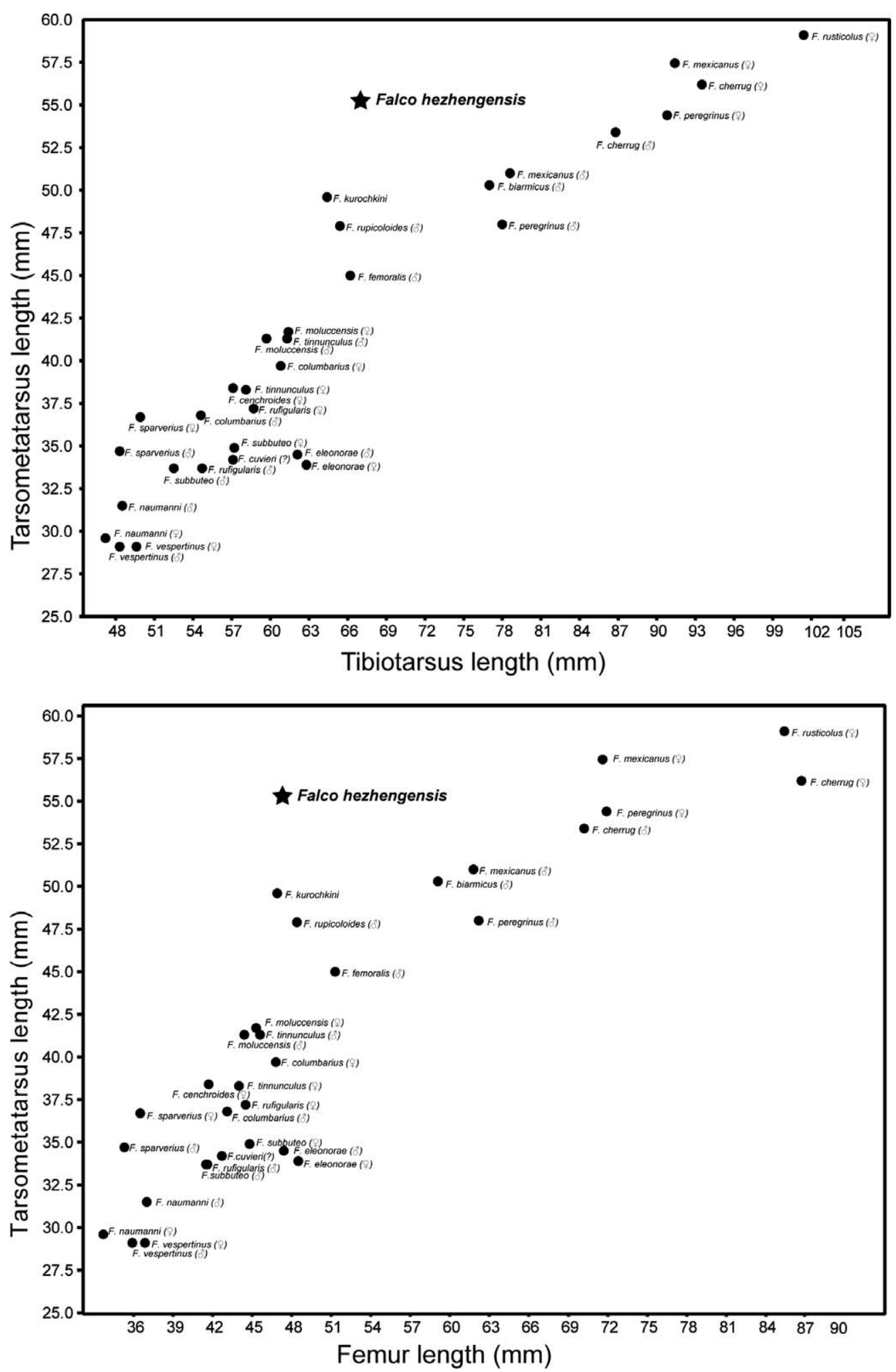

FIGURE 3. Scatter plots showing the lengths of the tibiotarsus (A) and femur (B) in relation to the length of the tarsometatarsus in Falco hezhengensis and other falcons; data are from Table 1. Most size variation in Falco is due to sexual dimorphism (Solti 1981, 1996). Compared with the measurements of limb length from 19 male and female falcons, $F$. hezhengensis is distinct in hindlimb proportions. 


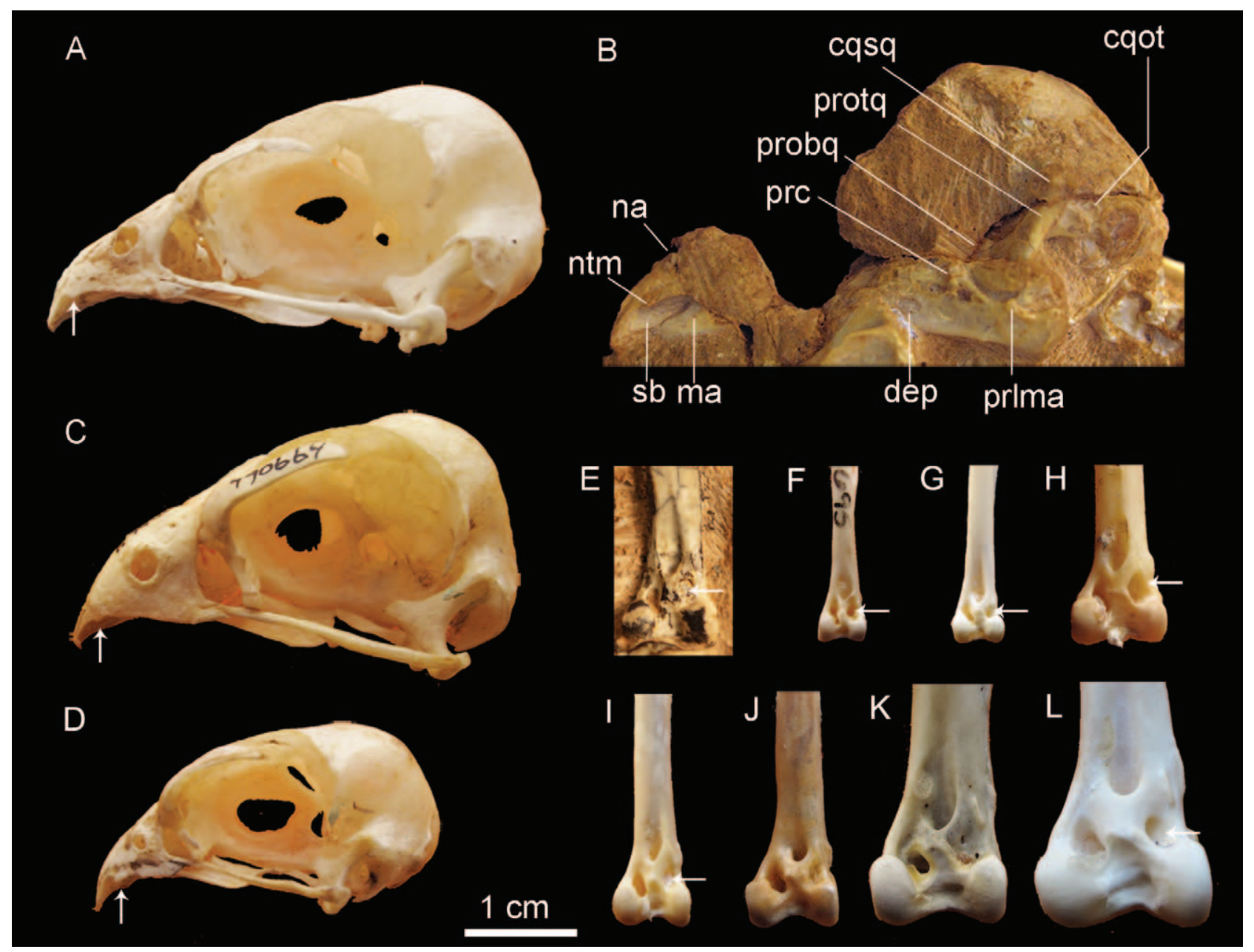

FIGURE 4. Comparison of the skull and distal tibiotarsus of the holotype Falco hezhengensis with other Falconidae species: (A) F. tinnuculus (USNM 610371); (B, E) F. hezhengensis (IVPP V14586); (C) Polihierax insignis (USNM 490664); (D, F) Microhierax erythrogenys (USNM 613695); (G) P. semitorquatus (USNM 621024); (H) F. rupicoloides (USNM 430626); (I) Spiziapteryx circumcincta (USNM 319445); (J) Micrastur ruficollis (USNM 621387); (K) Herpetotheres cachinnans (USNM 346714); and (L) Caracara plancus (USNM 614583). The vertical arrows indicate the tomial notch on the premaxilla that is present in Falconinae; the horizontal arrows indicate a third opening into the extensor groove located medial to the supratendinal bridge that is present in Falconinae and Polyborinae but not in Herpetotherinae. Anatomical abbreviations: $c q o t=$ cotyla quadrati otici, $c q s q=$ cotyla quadrati squamosa, dep $=$ depression, $\mathrm{ma}=$ mandible, $\mathrm{na}=$ naris, $\mathrm{ntm}=$ notched tomial margin, $\mathrm{prc}=$ processus coronoideus, $\mathrm{prlma}=$ processus lateralis mandibulae, probq $=$ processus orbitalis quadrati, protq $=$ processus oticus quadrati, and $\mathrm{sb}=$ septal bar.

vertebrae visible between the left coracoid and the scapula are likely to represent the vertebrate of the 11th to the 14th, which are characterized by possessing high neural spines and prominent ventral processes (Figure 5A: tv). Near the midseries cervicals, as well as close to the coracoids, clusters of delicate tracheal rings are visible (Figure 5A). The diameter of the tracheal rings is about 4$5 \mathrm{~mm}$, and individual ring width ranges from 0.5 to $1 \mathrm{~mm}$.

The left coracoid and scapula are exposed in lateral view (Figure 5A); the coracoid is missing its sternal margin. The short acrocoracoid process is deflected slightly ventromedially. The furcular facet is slightly inclined. The supracoracoid nerve foramen and the procoracoid process are not exposed. The left scapula is nearly straight, with a slight distal expansion; its distalmost tip is not preserved. The furcula is broken near the apophysis (Figure 5A). The furcular rami are broad and highly mediolaterally compressed, with a width similar to that observed in other Falco. They are broader than those of Polihierax, Spiziapteryx, and Microhierax, and also similar to those of some Polyborinae, but less robust. The acrocoracoid process of the furcula (proc. acrocor.; Baumel and Witmer 1993) is developed as a projected facet with a raised cranial margin. Medially, a pneumatic foramen (Figure 5A: pnf) is visible, similar to other Falco (e.g., F. peregrinus). The sternum is preserved in left-lateral view, but it has been 


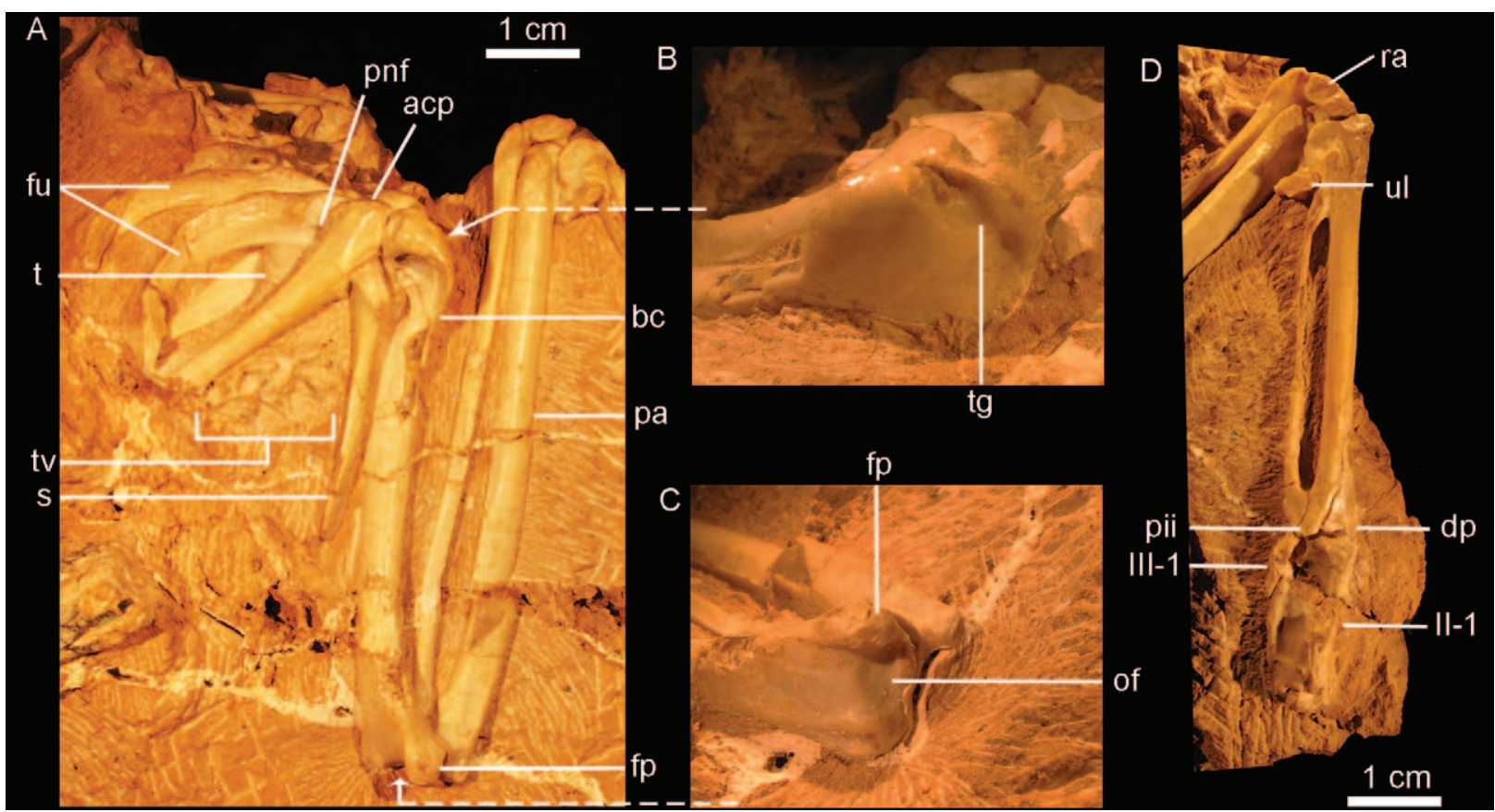

FIGURE 5. (A) Detail of pectoral girdle and wing of the holotype Falco hezhengensis, with humerus in ventral view; (B) detail of the proximal humerus in cranioventral view; (C) detail of the distal humerus in caudal view; and (D) distal portions of the forelimb. Anatomical abbreviations: $a c p=$ acrocoracoid process, $b c=$ bicipital crest, $d p=$ dorsal process, $f p=$ flexor process, $f u=f u r c u l a, ~ o f=$ olecranon fossa, $\mathrm{pa}=$ papillae remigalis caudalis, $\mathrm{pii}=$ processus internus indicis (internal index process), $\mathrm{ra}=\mathrm{radiale}, \mathrm{s}=\mathrm{scapula}, \mathrm{tg}$ $=$ transverse groove, $\mathrm{tv}=$ thoracic vertebrae, $\mathrm{ul}=$ ulnare, $\mathrm{II}-1=$ phalanx II-1, and III-1 = phalanx III-1.

badly crushed (Figure 1). The left craniolateral process of the sternum as well as its keel and left lateral margin are discernible. The caudal margin of the sternum is crushed, and its fragments are mixed with the bones from a small rodent (Figures 1 and 7). Identifiable elements of the rodent include dentaries with incisors and molars $(\mathrm{m} 1, \mathrm{~m} 2$, $\mathrm{m} 3$ ), the rostral portion of the left premaxilla with an intact incisor, and incomplete vertebrae.

The left forelimb is better exposed than the right. On the primary surface of the block, most of the left humerus is exposed in caudoventral view as well as part of the right humerus, including the edge of the bicipital crest and ventral tubercle (Figures 1 and 5). The craniodorsal margin of the right humerus has also been prepared from the other side of the block. The humeral shaft is essentially straight, as in other falcons and Polyborinae. It is more sigmoidal in other Falconidae. The bicipital crest meets the humeral shaft obliquely, as in other Falco and the Polyborinae (Figure 5A: bc). This contact is closer to a right angle in Herpetotheres and Micrastur, in which the crest also has a more limited distal extent down the humeral shaft. The transverse groove (sulcus lig. transversus; Baumel and Witmer 1993) in F. hezhengensis is similar to that of other Falco and the Polyborinae and more marked than in the rest of Falconidae. The groove in

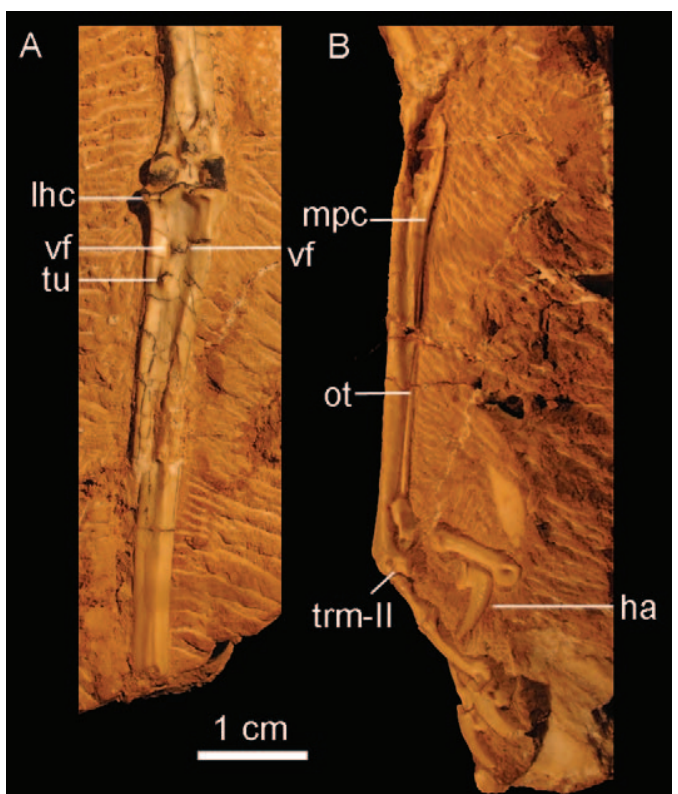

FIGURE 6. Left (A) and right (B) tarsometatarsi in dorsal and leftlateral view of the holotype Falco hezhengensis. Anatomical abbreviations: $\mathrm{mpc}=$ medial plantar crest, ha=hallucal claw, Ihc $=$ lateral hypotarsal crest, ot $=$ ossified tendon, trm- $I I=$ trochea metatarsi II, tu $=$ tubercles of $\mathrm{m}$. tibialis cranialis, and $\mathrm{vf}=$ vascular foramen. 


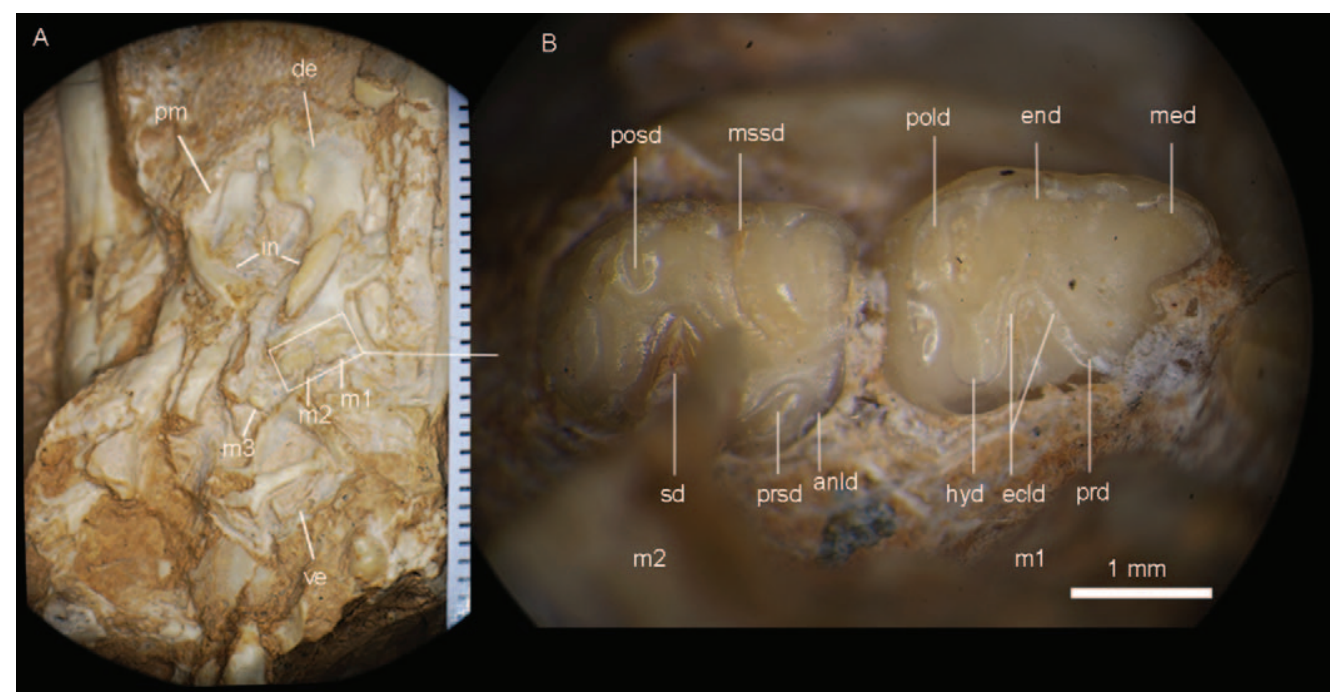

FIGURE 7. (A) Jerboa (cf. Dipus fraudator) remains preserved in the abdominal region of Falco hezhengensis (IVPP V14586) and (B) detail of the molar 1 and 2 in occlusal view. Anatomical abbreviations: de = dentary, ecld = ectolophid, end = entoconid, hyd = hypoconid, in = incisor, med = metaconid, $\mathrm{mssd}=$ mesosinusid, $\mathrm{m} 1-\mathrm{m} 3=$ molar $1-3, \mathrm{pm}=$ premaxilla, pold $=$ posterolophid, posd $=$ posterosinusid, $\mathrm{prd}=$ protoconid, prsd = protosinusid, and $\mathrm{sd}=$ sinusoid. Cusps and valleys are labeled for $\mathrm{m} 1$ and $\mathrm{m} 2$; terminology follows that of Li and Qiu (2005).

Falco is essentially deep throughout its length (Figure 5B: tg), unlike the condition in other Falconidae (e.g., Herpetotheres and Polihierax) in which the transverse groove becomes shallower toward the humeral midline. The proximocaudal surface of the deltopectoral crest is concave. Distally, the olecranon fossa is rounded and slightly deeper than in other Falco (Figure 5C: of). The flexor process distally surpasses the ventral condyle (Figure 5A, 5C: fp), as seen in other Falco. This process is variably developed in Falconidae; it is least projected distally in Polyborinae, in which it does not surpass the ventral condyle. In other taxa (e.g., Micrastur), it is even with this condyle in distal extent.

The ulna is longer than the humerus (humerus:ulna ratio $=0.9$ ). Six slightly raised ovoid scars representing papillae remigales ventrales (Baumel and Witmer 1993) are evenly distributed along the ventral surface of the ulna (Figure 5A: pa). Dorsally, a series of shallow depressions also mark the dorsal attachments of the remiges. The ulnare and radiale are preserved in articulation with the carpometacarpus on both sides (Figure 5A, 5D). Although the dorsal ramus of the ulnare is partially covered by the carpometacarpus, it appears to be similar in length to the ventral ramus as in other Falco. The carpometacarpi are exposed in ventral view and about half the length of the ulnae. Metacarpal III slightly surpasses metacarpal II in distal extent, and a dorsal process is developed distally on metacarpal II (Figure 5D: dp). A small internal index process (Figure 5D: pii) is developed on manual digit II:1, and a flexor process is present on digit III:1 (Figure 5D). In these morphologies, the new species is similar to other Falco. Metacarpal III is slightly curved in Micrastur and Herpetotheres; it is straight in the new Falco and other Falconinae. Right digit I: 1 is partially preserved and appears to be robust compared with the condition in other Falco.

The pelvic girdle is obscured by matrix. The femur is slightly more curved and stouter than extant Falco of similar body size (e.g., F. rupicoloides and F. tinnunculus). The trochanteric crest is only weakly projected proximally. The medial epicondyle bears a depression for the medial collateral ligament. A patella is present, contacting the right femur distally. The right tibiotarsus is exposed in cranial and medial view. The cranial cnemial crest (crista cnemialis cranialis; Baumel and Witmer 1993) is very weakly projected, forming only a low ridge. By contrast, in Polyborinae this crest is significantly more expanded cranially. Distally, the supratendinal bridge is narrow, and its proximal margin angles strongly medially. A large ovoid opening is present medial to the supratendinal bridge in the left tibiotarsus (Figure 4E). This opening is present in taxa of Polyborinae and Falconinae, but absent from taxa of Herpetotherinae (Figure 4J, 4K), in which only a shallow depression is present in this location. The lateral retinaculum tubercle extends to the lateral epicondyle. The intercondylar groove is slightly deeper than that of extant falcons. The fibula is about $3 / 4$ the length of tibiotarsus. It is fused with the tibiotarsus distally to enclose a long and narrow interosseous foramen (Figure $1)$. 
The tarsometatarsus is slender and only slightly shorter than the tibiotarsus. The ratio of tarsometatarsus to tibiotarsus length in $F$. hezhengensis differs from other extant and extinct Falco (Tables 1 and 2; Figure 3). The lateral hypotarsal crest is directed plantarly (Figure 6A: lhc) rather than more laterally as in Polyborinae. Two proximal vascular foramina are present (Figure 6A: vf). An $\mathrm{m}$. tibialis cranialis tubercle (Figure 6A: tu) is medially located, just distal to the more medial of these foramina, and more prominent than in other Falco. An extensor sulcus extends down the cranial surface of the tarsometatarsus shaft; it is limited in distal extent compared with the Herpetotherinae but similar in development to other Falco and Polyborinae. The medial hypotarsal crest of the right tarsometatarsus is partially exposed. This crest extends down the plantar surface of the shaft, where it joins the medial plantar crest distally (Figure 6B: mpc). An ossified tendon is adhered to the plantar surface of the right tarsometatarsus (Figure 6B: ot). Only the trochlea of metatarsal II is visible; it is slightly laterally deflected (Figure 6B). Pedal phalanges are preserved in partial articulation with the right tarsometatarsus. The proximalmost phalanges of digits II and III are significantly shorter than the more distal phalanges. The claw of the hallux is slightly larger than the other unguals. All pedal claws have well-developed flexor tubercles and pits. The flexor tubercle of the second digit ungual is slightly larger than those of the other digits.

Phylogenetic analysis and results. To assess the phylogenetic position of the new specimen, analysis of 66 osteological characters (63 PIC, all unordered and equally weighted) was undertaken for 15 ingroup Falconidae taxa and 3 outgroup taxa using PAUP* version 4.10b (Swofford 2003; branch and bound search, amb- [collapsing minimum 0 length branches], polymorphism differentiated from ambiguity). The osteological character set is based on the observations of Jollie (1976, 1977a, 1977b, 1977c) and the character set of Noriega et al. (2011) as well as the reexamination of skeletal features in Falconidae. Thirtyeight characters are new to this analysis (Supplemental Material Appendix S1).

Multiple skeletal materials (of males and females) were examined to ensure that character evaluation took into account intraspecific variation. The 2 other well-preserved Miocene fossil Falconidae (Pediohierax and Thegornis) were scored from illustrations and descriptions in the literature (Becker 1987, Noriega et al. 2011). Circus buffoni and Buteo lagopus (Accipitridae) were originally utilized as outgroup taxa in the analysis, on the basis of previous phylogenetic analyses of both molecular and morphological data (Pereira and Baker 2006, Livezey and Zusi 2007, Pacheco et al. 2011). Other recent molecular analyses of relationships within Falconidae have also utilized accipitrid outgroups (Fuchs et al. 2011, 2012). However, more recent analyses have not recovered this sister-taxon relationship. They instead find Falconidae to be placed near the base of a clade including parrots, songbirds, and the enigmatic raptorial taxon Cariamidae (Hackett et al. 2008, McCormack et al. 2013, Yuri et al. 2013). One of the 2 extant cariamids, Cariama cristata, was used to replace the accipitrid taxa to investigate the effect of outgroup choice on estimated ingroup relationships.

Two most parsimonious trees were recovered from the primary analysis. The strict consensus cladogram (Figure 8) agrees with previous analyses of Falconidae in recovery of the monophyly of 3 major subclades, the sister-taxon relationship between Polyborinae and Falconinae, as well as most species-level relationships (Griffiths 1999, Griffiths et al. 2004, Fuchs et al. 2011, 2012). Swapping in C. cristata as an outgroup yielded only 1 topological difference in the single resultant most parsimonious tree (length $=150$; consistency index $[\mathrm{CI}]=0.63$; retention index $[\mathrm{RI}]=0.77$; rescaled consistency index $[R C]=0.49$ ); a polytomy within Herpetotherinae is resolved with Micrastur basal to the sister taxa of Thegornis and Herpetotheres. Bootstrap support values for the primary analysis (1,000 replicates; branch and bound search) were computed in PAUP* and are reported in Figure 8.

In addition to the 2 diagnostic characters (characters 47 and 52), the monophyly of Falconidae is also supported by the other 6 unambiguously optimized synapomorphies (i.e. $11: 1,13: 0,17: 2,22: 1,30: 2,57: 1)$ in the primary analysis. Recovered as the sister taxon to the rest of Falconidae, the monophyletic Herpetotherinae is supported by 1 unambiguous synapomorphy (55:0, the long extensor sulcus on the dorsal surface of the tarsometatarsus). The placement of Spiziapteryx circumcincta (Spot-winged Falconet) within Falconinae is consistent with the analysis of Griffiths (1999). Spiziapteryx is supported as the sister taxon to the rest of Falconinae by 1 unambiguous synapomorphy (30:1, an elongate sheet-like procoracoid process with a pointed tip). It should be noted that in other recent analyses of mitochondrial data, Spiziapteryx has been recovered as the sister taxon to caracaras, and Caracara plancus was recovered to be basal within caracaras (Fuchs et al. 2011, 2012) rather than in the derived position recovered here. These analyses also utilized accipitrid outgroups. An additional analysis with the same parameters as the primary analysis but enforcing a backbone constraint tree representing the molecular phylogeny (Fuchs et al. 2011, 2012) for the relationships within caracaras and the position of Spiziapteryx did not affect the recovered placement of the new species (strict consensus cladogram of 2 most parsimonious trees; length $=166 ; \mathrm{CI}=0.61 ; \mathrm{RI}=$ $0.79 ; \mathrm{RC}=0.49$ ). The trees differed in the placement of Pediohierax, resulting in a polytomy at the base of the Falconinae; the recovered position of the new species was the same. 


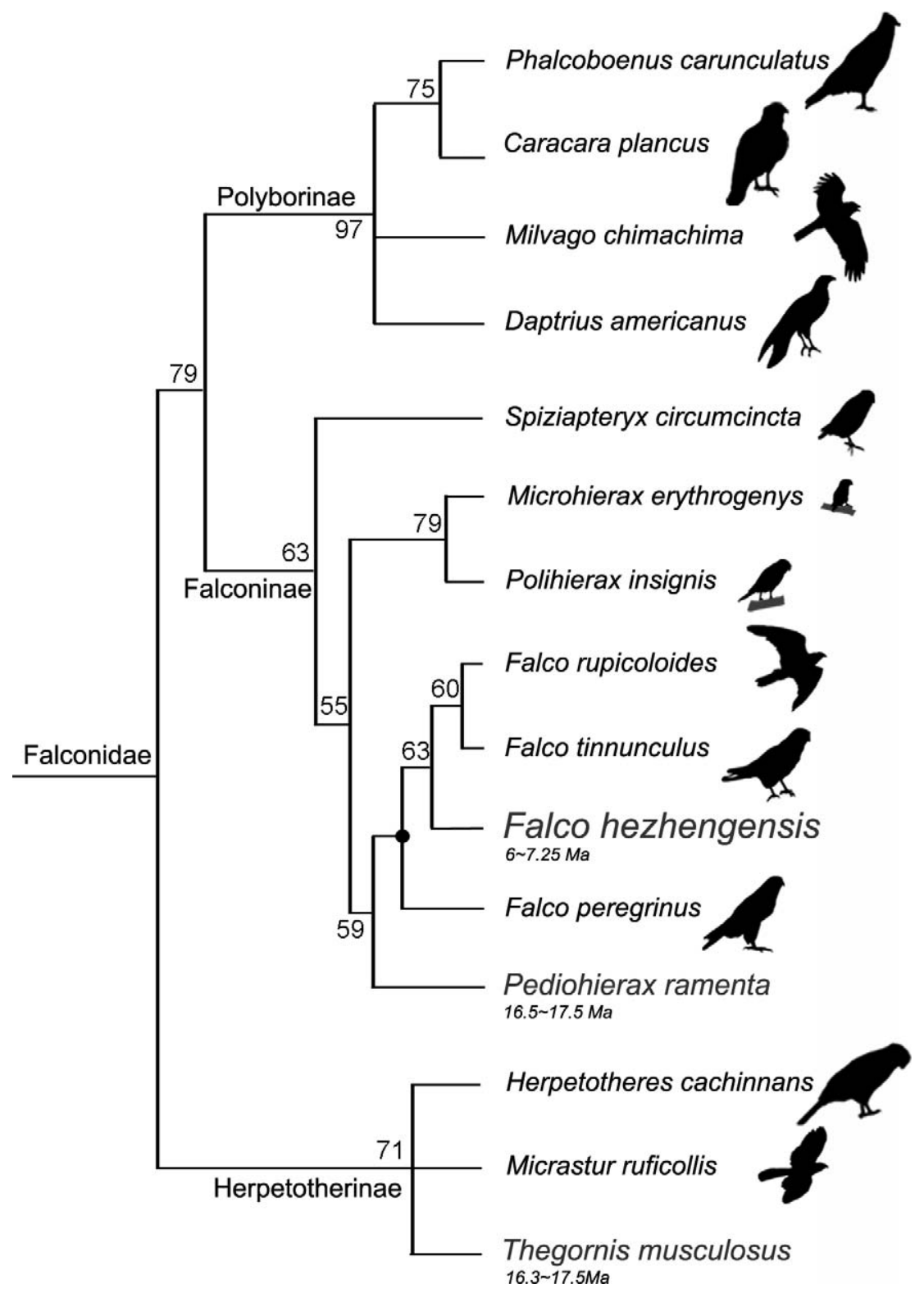

FIGURE 8. The phylogenetic affinities of the new species as recovered in the strict consensus cladogram of the 2 most parsimonious trees (length $=162 ; \mathrm{Cl}=0.62 ; \mathrm{Rl}=0.79 ; \mathrm{RC}=0.49$ ) from the primary phylogenetic analysis of 66 characters for 15 ingroup taxa; fossil taxa are shown in gray. Bootstrap support for those nodes recovered in $>50 \%$ of the 1,000 replicates performed are reported next to the node to which they apply. The single most parsimonious tree from analysis with a Cariama cristata outgroup is congruent with this summary cladogram as well (for details, see text; for the dataset, see Supplementary Material Appendices S1 and S2).

The new specimen is placed within Falco as the sister group of the extant kestrel species ( $F$. rupicoloides and $F$. tinnunculus; Figure 8). The relationship of $F$. hezhengensis with kestrels in relation to $F$. peregrinus is supported by 2 ambiguous synapomorphies (42:0, weak proximal projection of the trochanteric crest of the femur; and 63:1, very deep infracotylar fossa in the tarsometatarsus). The Middle Miocene Pediohierax is recovered outside of a clade including all extant Falco and the new species. The fossil
Thegornis is recovered with the extant species in Herpetotherinae, consistent with its previously recovered placement (Noriega et al. 2011).

\section{DISCUSSION}

Falco hezhengensis is most similar in size and limb proportions to F. rupicoloides (Greater Kestrel). Both birds are slightly larger than other kestrels (Solti 1996) but 
smaller than most other falcon species, especially the large-sized Peregrine and Saker falcons (F. peregrinus and F. cherrug; see Tables 1 and 2; also see Solti 1981). Within Falco, kestrels are distinctive in their hovering flight style, hunting behavior, and appearance, with long wings, long tails, and short toes. Unlike other Falco, their prey are almost exclusively terrestrial animals (e.g., small mammals, lizards, amphibians) and insects. Examination of the tarsometatarsus length in extant Falco (Tables 1 and 2) and additional data from the literature (Solti 1981, 1996, Village 1990, White et al. 1994) identifies F. hezhengensis as unique in its elongate distal hindlimb and abbreviate digit III, especially compared with falcons of similar size. The structure of the foot has been suggested to correlate with hunting techniques in falcons (Village 1990, White et al. 1994, Suárez and Olson 2001), and the slender hindlimb elements coupled with the shorter pedal digits suggests that the feeding ecology of $F$. hezhengensis was probably indeed more kestrel-like: searching for and targeting small ground-dwelling animals while perched or hovering. The phylogenetic position of $F$. hezhengensis with extant kestrels is consistent with a single origin of the special feeding ecology, associated with generally more elongate hindlimb proportions within Falco.

Because of the scarcity of well-preserved fossil Falconidae, only 1 species, Pediohierax ramenta, was used to constrain the minimum age of the divergence of Falconinae from Polyborinae to the Middle Miocene (Becker 1987, Fuchs et al. 2012). The new species provides another reliable internal calibration for Falconidae, dating the earliest divergence of kestrels from the Peregrine Falcon by the Late Miocene. The genus Falco, including kestrels, hobbies, and other larger true falcons, is believed to have radiated during the Late Miocene through the Early Pleistocene (White et al. 1994), but the timing and location of the radiation is still ambiguous given limited fossil occurrences over a wide geographic range (e.g., Eurasia, North America, and South America). Kestrels have been proposed to have an African origin, based on the distribution and proposed phylogenetic relationships among extant species (Groombridge et al. 2002), but no pre-Pleistocene fossil remains are known from Africa. The new specimen may represent an early dispersal event after the origin of kestrels; alternatively, it also could be interpreted as evidence that a Eurasian origin of kestrels should be considered. Indeed, most early Falco specimens are from Europe and Asia (Umanskaja 1981, Becker 1987, Boev 2011a, 2011b).

The rodent remains preserved in the abdominal region of the articulated holotype specimen of $F$. hezhengensis may provide direct evidence of diet. A jerboa (Rodentia: Dipodidae) affinity for the remains is supported. The morphologies of molars 1 and 2, preserved in the right dentary, are nearly identical to the extant genus of jerboas,
Dipus (Figure 7). Both $\mathrm{m} 1$ and $\mathrm{m} 2$ are lophodont and have only 4 basic cusps (hypoconid, metaconid, protoconid, and entoconid), with the lingual cusps located slightly cranial to the labial ones (Qiu 2003). The conical metaconid (Figure 7B: med) is the largest cusp in $\mathrm{m} 1$, with a relatively cranial position to the protocoid (Figure 7: prd). The posterosinusid between the entoconid and the posterolophid in $\mathrm{m} 2$ is wider than that of Pliocene to recent Dipus, but similar to that of Dipus from Miocene localities (Qiu and Storch 2000, Li and Qiu 2005, Liu et al. 2008; Figure 7B). The upper incisors bear longitudinal grooves similar to all other Dipus (Figure 7A). Currently, the earliest record of Dipus is from Late Miocene-Early Pliocene deposits of northwestern China (Qiu and Storch 2000, Qiu 2003), and similar Dipus species (Dipus spp.) have also been reported from Heshui and Lingtai of Gansu Province with nearly identical dental morphologies ( $\mathrm{Li}$ and Qiu 2005; Figure 2). On the basis of molecular divergence dating approaches, jerboas have also been estimated to originate in the Miocene (Zhang et al. 2012).

Because all known species of Dipus (both extinct and extant) are morphologically nearly identical, size has been used to diagnose distinct species (Qiu 2003, Li and Qiu 2005). The maximum length and width of $\mathrm{m} 1$ in the preserved remains are $\sim 2.1$ and $\sim 1.6 \mathrm{~mm}$, respectively, dimensions that are most similar to those reported for Dipus fraudator $(2 \times 1.6 \mathrm{~mm})$. The specimen falls within known size ranges for this species from 3 localities: Bilike (Inner Mongolia), Ertemte (Inner Mongolia), and Loc. 30 of Baode (Shanxi; Qiu and Storch 2000, Qiu 2003, Liu et al. 2008). It is most similar to material from the Late Miocene Loc. 30 of Baode in possessing a wider posterosinusid (Figure 7B: posd), further supporting the provenance of the specimen from the upper part of the Liushu Formation, with an age of 6-7.25 Ma (Qui and Wang 1998, Deng et al. 2013).

The diversity and abundance of jerboas in Miocene localities has been proposed to indicate that they were a major component of the small mammal fauna, especially in relation to the present day (Zazhigin and Lopatin 2001, Qiu 2003, Li and Qiu 2005). Because other small rodents (voles and mice; Yalden and Yalden 1985, Village 1990) that make up a greater percentage of the kestrel diet today are also rare in Miocene fauna (Deng et al. 2013), we believe that the jerboa remains likely represent a component of the diet of the new species. However, as with any fossil evidence of this kind, we cannot rule out the possibility of accidental ingestion.

Falco hezhengensis provides additional insight into the diversity in the Late Miocene Hipparion fauna from Linxia Basin, which is characterized by extremely abundant mammalian fossil specimens but limited described avian remains. Two avian species were described prior to $F$. hezhengensis: a large-bodied ostrich, Struthio linxiaensis (Hou et al. 2005), and an Old World vulture, Gansugyps 
linxiaensis (Zhang et al. 2010) from 2 localities in Guanghe (Figure 2). While Gansugyps has been proposed to feed on the carcasses of large plain-dwelling herbivores, the significantly smaller $F$. hezhengensis would fill a distinct niche, evidently preying on small mammals and, perhaps, small reptiles. The only modern environment where relatives of the 3 Linxia avian species and jerboas are copresent today is the African savanna.

In many parts of Central Asia and northwestern China, increased aridification combined with strengthening of the monsoon effect has been linked to the extinction of a significant number of mammalian species at the PliocenePleistocene boundary (Qiu and Li 2005, Zhang 2006). Seasonal variation in northwestern China is estimated to have begun increasing in the Late Miocene, related to increased monsoonal intensity and Himalayan uplift (Song et al. 2007). The Late Pleistocene disappearance of ostriches from the Asian steppes (Kurochkin et al. 2010) as well as possible shifts in predator-prey relationships further support significant recent changes in the avifauna of these arid steppe environments. Today, jerboas have been reported to be the primary prey of the Little Owl (Athene noctua) in Central Asia (Lay 1974); they have not been described as part of the common diet of any extant kestrel species. Other species of rodents and insectivores (e.g., mice, voles, and shrews) dominate the diet of these taxa (Yalden and Yalden 1985). Jerboas (Dipodidae), and other mammalian species abundant in Miocene deposits, remain abundant into the Late Pliocene (Fortelius and Zhang 2006, Zhang 2006, Deng et al. 2013) but are far more rare in present-day Central Asia. If the jerboa remains described here are properly interpreted as evidence of the diet of $F$. hezhengensis, as we suggest, they and the unique hindlimb proportions in the new species may indicate a shift in kestrel diet and ecology between the Late Miocene and the present day. Such a shift would be consistent with previously reported Late Neogene turnover and environmental change in these steppe communities (Qiu and Li 2005, Zhang 2006, Song et al. 2007, Kurochkin et al. 2010).

\section{ACKNOWLEDGMENTS}

We thank R. Migotto for discussion, K. Bader and R. Salas for comments on the manuscript, and R. Burroughs for help with the translation of the abstract. We are grateful to $\mathrm{H}$. James and C. Milensky for hosting the authors during their visits to Smithsonian Institution. Three anonymous reviewers provided helpful comments on the manuscript. This research was supported by the National Basic Research Program of China (973 Program; 2012CB821906); the National Natural Science Foundation of China; the Chinese Academy of Sciences (Z.Z.); the Jackson School of Geosciences, University of Texas at Austin (J.C. and L.Z.); and by a Predoctoral Fellowship from the Smithsonian Institute (L.Z.).

\section{LITERATURE CITED}

Ameghino, F. (1895). Sur les oiseaux fossiles de Patagonie. Boletín del Instituto Geográ fico Argentino 15:301-660.

Baumel, J. J., and L. M. Witmer (1993). Osteologia. In Handbook of Avian Anatomy: Nomina Anatomica Avium, second edition. (J. J. Baumel, A. S. King, J. E. Breazile, H. E. Evans, and J. C. Vanden Berge, Editors). Publications of the Nuttall Ornithological Club 23. pp. 45-132.

Becker, J. J. (1987). Revision of "Falco" ramenta Wetmore and the Neogene evolution of the Falconidae. The Auk 104:270276.

Boev, Z. (2011a). Falco bulgaricus sp. n. (Aves: Falconiformes) from the Late Miocene of Hadzhidimovo (SW Bulgaria). Acta Zoologica Bulgarica 63:17-35.

Boev, Z. (2011b). New fossil record of the Late Pliocene kestrel (Falco bakalovi Boev, 1999) from the type locality in Bulgaria. Geologica Balcanica 40:13-30.

Csermely, D., L. Bertè, and R. Camoni (1998). Prey killing by Eurasian Kestrels: The role of the foot and the significance of bill and talons. Journal of Avian Biology 29:10-16.

Deng, T. (2005). Character, age and ecology of the Hezheng Biota from northwestern China. Acta Geologica Sinica 79: 739-750.

Deng, T. (2006). Paleoecological comparison between Late Miocene localities of China and Greece based on Hipparion faunas. Geodiversitas 28:499-516.

Deng, T., Z. Qiu, B. Wang, X. Wang, and S. Hou (2013). Late Cenozoic biostratigraphy of the Linxia Basin, northwestern China. In Fossil Mammals of Asia: Neogene Biostratigraphy and Chronology (X. M. Wang, L. J. Flynn, and M. Fortelius, Editors). Columbia University Press, New York, NY, USA. pp. 243-273.

Emslie, S. D., and C. G. Correa (2003). A new species of penguin (Spheniscidae: Spheniscus) and other birds from the Late Pliocene of Chile. Proceedings of the Biological Society of Washington 116:308-316.

Fang, X. M., C. Garzione, R. Van der Voo, J. J. Li, and M. J. Fan (2003). Flexural subsidence by $29 \mathrm{Ma}$ on the NE edge of Tibet from the magnetostratigraphy of Linxia Basin, China. Earth and Planetary Science Letters 210:545-560.

Feduccia, A. (1999). The Origin and Evolution of Birds, second edition. Yale University Press, New Haven, CT, USA.

Fortelius, M., and Z. Zhang (2006). An oasis in the desert? History of endemism and climate in the Late Neogene of North China. Palaeontographica A 277:131-141.

Fuchs, J., S. Chen, J. A. Johnson, and D. P. Mindell (2011). Pliocene diversification within the South American forest falcons (Falconidae: Micrastur). Molecular Phylogenetics and Evolution 60:398-407.

Fuchs, J., J. A. Johnson, and D. P. Mindell (2012). Molecular systematics of the caracaras and allies (Falconidae: Polyborinae) inferred from mitochondrial and nuclear sequence data. Ibis 154:520-532.

Griffiths, C. S. (1999). Phylogeny of the Falconidae inferred from molecular and morphological data. The Auk 116:116-130.

Griffiths, C. S., G. F. Barrowclough, J. G. Groth, and L. Mertz (2004). Phylogeny of the Falconidae (Aves): A comparison of the efficacy of morphological, mitochondrial, and nuclear data. Molecular Phylogenetics and Evolution 32:101-109. 
Groombridge, J. J., C. G. Jones, M. K. Bayes, A. J. van Zyl, J. Carrillo, R. A. Nichols, and M. W. Bruford (2002). A molecular phylogeny of African kestrels with reference to divergence across the Indian Ocean. Molecular Phylogenetics and Evolution 25:267-277.

Hackett S. J., R. T. Kimball, S. Reddy, R. C. K. Bowie, E. L. Braun, M. J. Braun, J. L. Chojnowski, W. A. Cox, K.-L. Han, J. Harshman, C. J. Huddleston, B. D. Marks, et al. (2008). A phylogenomic study of birds reveals their evolutionary history. Science 320 : 1763-1768.

Hou, L., Z. Zhou, F. Zhang, and Z. Wang (2005). A Miocene ostrich fossil from Gansu Province, northwest China. Chinese Science Bulletin 50:1808-1810.

Jollie, M. (1976). A contribution to the morphology and phylogeny of the Falconiformes, part 1. Evolutionary Theory 1:285-298.

Jollie, M. (1977a). A contribution to the morphology and phylogeny of the Falconiformes, part 2. Evolutionary Theory 2:115-208.

Jollie, M. (1977b). A contribution to the morphology and phylogeny of the Falconiformes, part 3. Evolutionary Theory 2:209-300.

Jollie, M. (1977c). A contribution to the morphology and phylogeny of the Falconiformes, part 4. Evolutionary Theory 3:1-142.

Kurochkin, E. N., Y. V. Kuzmin, I. V. Antoshchenko-Olenev, V. I. Zabelin, S. K. Krivonogov, T. I. Nohrina, L. V. Lbova, G. S. Burr, and R. J. Cruz (2010). The timing of ostrich existence in Central Asia: AMS ${ }^{14} \mathrm{C}$ age of eggshells from Mongolia and southern Siberia (a pilot study). Nuclear Instruments and Methods in Physics Research B 268:1091-1093.

Lay, D. M. (1974). Differential predation on gerbils (Meriones) by the Little Owl, Athene brahma. Journal of Mammalogy 55: 608-614.

Li, Q., and Z. Qiu (2005). Restudies in Sminthoides schlosser, a fossil genus of three-toed jerboa from China. Vertebrata PalAsiatica 43:24-35. [In Chinese, English abstract.]

Liu, L., Z. Zhang, N. Cun, and M. Fortelius (2008). The Dipodidae (jerboas) from Loc. 30 of Baode and their environmental significance. Vertebrata PalAsiatica 46:124-132.

Livezey, B. C., and R. L. Zusi (2007). Higher-order phylogeny of modern birds (Theropoda, Aves: Neornithes) based on comparative anatomy. II. Analysis and discussion. Zoological Journal of the Linnean Society 149:1-95.

Mayr, G. (2006). A new raptorial bird from the Middle Eocene of Messel, Germany. Historical Biology 18:95-102.

Mayr, G. (2009a). A well-preserved skull of the "falconiform" bird Masillaraptor from the Middle Eocene of Messel (Germany). Palaeodiversity 2:315-320.

Mayr, G. (Editor) (2009b). Paleogene Fossil Birds. Springer, Heidelberg, Germany.

McCormack, J. E., M. G. Harvey, B. C. Faircloth, N. G. Crawford, T. C. Glenn, and R. T. Brumfield (2013). A phylogeny of birds based on over 1,500 loci collected by target enrichment and high-throughput sequencing. PloS ONE 8(1):e54848.

Noriega, J. I., J. I. Areta, S. F. Vizcaíno, and M. S. Bargo (2011). Phylogeny and taxonomy of the Patagonian Miocene falcon Thegornis musculosus Ameghino, 1895 (Aves: Falconidae). Journal of Paleontology 85:1089-1104.

Pacheco, M. A., F. U. Battistuzzi, M. Lentino, R. F. Aguilar, S. Kumar, and A. A. Escalante (2011). Evolution of modern birds revealed by mitogenomics: Timing the radiation and origin of major orders. Molecular Biology and Evolution 28:1927-1942.

Pereira, S. L., and A. J. Baker (2006). A mitogenomic timescale for birds detects variable phylogenetic rates of molecular evolution and refutes the standard molecular clock. Molecular Phylogenetics and Evolution 23:1731-1740.

Qiu, Z. (2003). The Neogene mammalian faunas of Ertemte and Harr Obo in Inner Mongolia (Nei Mongol), China: Jerboas. Senckenbergiana Lethaea 83:135-147.

Qiu, Z., and C. Li (2005). Evolution of Chinese mammalian faunal regions and elevation of the Qinghai-Xizang (Tibet) Plateau. Science in China D 48:1246-1258.

Qiu, Z., and G. Storch (2000). The Early Pliocene micromammalian fauna of Bilike, Inner Mongolia, China (Mammalia: Lipotyphla, Chiroptera, Rodentia, Lagomorpha). Senckenbergiana Lethaea 80:173-229.

Qiu, Z., and X. Wang (1998). Small mammal faunas and their ages in Miocene of central Nei Mongol (Inner Mongolia). Vertebrata PalAsiatica 37:120-139.

Solti, B. (1981). Vergleichend osteologische Untersuchungen am Skelettsystem der Falkenarten Falco cherrug Gray und Falco peregrinus Tunstall. Vertebrata Hungarica 20:75-125.

Solti, B. (1996). The comparative osteomorphological study of the European small-statured falcons (Aves: Falconidae). Folia Historica Naturalia Musei Matraensis 21:5-282.

Song, C., X. Lu. Q. Xing, Q. Meng, W. Xia, P. Liu, and P. Zhang (2007). Late Cenozoic element characters and palaeoclimatic change of the lacustrine sediments in the Linxia Basin, China. Acta Sedimentologica Sinica 25:409-416.

Suárez, W., and S. L. Olson (2001). A remarkable new species of small falcon from the Quaternary of Cuba (Aves: Falconidae: Falco). Proceedings of the Biological Society of Washington 114:34-41.

Swofford, D. L. (2003). PAUP*: Phylogenetic Analysis Using Parsimony (*and Other Methods). Sinauer Associates, Sunderland, MA, USA.

Tambussi, C., and C. Acosta Hospitaleche (2007). Antarctic birds (Neornithes) during the Cretaceous-Eocene times. Revista de la Asociación Geológica Argentina 62:604-617.

Tambussi, C. P., and F. Degrange (2013). South American and Antarctic Continental Cenozoic Birds: Paleobiogeographic Affinities and Disparities. Springer, New York, NY, USA.

Umanskaja, A. S. (1981). The Miocene birds of the western Black Sea coasts of the Ukrainian SSR. Vestnik Zoologii 17:17-21. [In Russian with English summary.]

Village, A. (1990). The Kestrel. T. \& A.D. Poyser, London, UK.

Wetmore, A. (1936). Two new species of hawks from the Miocene of Nebraska. Proceedings of the National Academy of Sciences USA 84:73-78.

White, C., P. Olsen, and L. Kiff (1994). Family Falconidae (Falcons and Caracaras). In Handbook of the Birds of the World, vol. 2 (J. del Hoyo, A. Elliott, and J. Sargatal, Editors). Lynx Edicions, Barcelona, Spain. pp. 216-275.

Yalden, D. W., and P. E. Yalden (1985). An experimental investigation of examining kestrel diet by pellet analysis. Bird Study 32:50-55.

Yuri, T., R. T. Kimball, J. Harshman, R. C. K. Bowie, M. J. Braun, J. L. Chojnowski, K.-L. Han, S. J. Hackett, C. J. Huddleston, W. S. Moore, S. Reddy, F. H. Sheldon, et al. (2013). Parsimony and model-based analyses of indels in avian nuclear genes reveal 
congruent and incongruent phylogenetic signals. Biology 2: 419-444.

Zazhigin, V. S., and A. V. Lopatin (2001). The history of the Dipodoidea (Rodentia, Mammalia) in the Miocene of Asia: 4. Dipodinae at the Miocene-Pliocene transition. Paleontologicheskii Zhurnal 1:61-75.

Zhang, Q., L. Xia, Y. Kimura, G. Shenbrot, Z. Zhang, D. Ge, and Q. Yang (2012). Tracing the origin and diversification of Dipodoidea (Order: Rodentia): Evidence from fossil record and molecular phylogeny. Evolutionary Biology 40:32-44.

Zhang, Z. (2006). Chinese Late Neogene land mammal community and the environmental changes of East Asia. Vertebrata PalAsiatica 44:133-142.

Zhang, Z., X. Zheng, G. Zheng, and L. Hou (2010). A new Old World vulture (Falconiformes: Accipitridae) from the Miocene of Gansu Province, northwest China. Journal of Ornithology 151:401-408. 